\title{
EDUCATION AND ENTREPRENEURSHIP INTEGRATION STRATEGY AT STATE ISLAMIC INSTITUTE OF BUKITTINGGI
}

\section{Harfandi}

State Islamic Institute of Bukittinggi, Indonesia

E-mail: harfandi@,iainbukittinggi.ac.id

\section{Era Sonita}

State Islamic Institute of Bukittinggi, Indonesia

E-mail: erasonita@iainbukittinggi.ac.id

\section{Zulhelmi}

State Islamic Institute of Bukittinggi, Indonesia

E-mail: zulhelmi@iainbukittinggi.ac.id

(C)2020 by the authors. Submitted for possible open access publication under the terms and conditions of the Creative Commons Attribution-ShareAlike 4.0 International License (CC-BY-SA)

license (https://creativecommons.org/licenses/by-sa/4.0/)

doi) $D O I: \underline{\text { http://dx.doi.org/10.30983/educative.v5i2.3156 }}$

Submission : March 16, $2020 \quad$ Revised: November 11, $2020 \quad$ Published: December 31,2020

\section{Abstract}

The increasing number of graduates from the State Islamic Institute of Bukittinggi (IAIN Bukittinggi) who do not have any competency will increase the number of unemployed in the society. In this regard, this study aimed to formulate strategies in integrating education with entrepreneurship at the State Islamic Institute of Bukittinggi in order to produce applicative and highly competitive graduates. After being analysed using SWOT analysis, SWOT Matrix, and Weight Score Table, it can be concluded that the right strategies are to implement the KKNI curriculum that meets market needs, develop curricula, in particular, entrepreneurship courses, equip students with adequate entrepreneurial knowledge, develop entrepreneurship training programmes, such as holding student business units to develop students' entrepreneurial potential, and multiplying student entrepreneurship practices through collaboration with business actors.

Keyword: integration, education, entrepreneurship

\section{Abstrak}

Bertambahnya lulusan Institut Agama Islam Negeri (LAIN) Bukittinggi yang tidak memiliki kompetensi dari tabun ketahun akan menambah jumlah pengangguran di tengah-tengah masyarakat. Sehubungan dengan itu, penelitian ini bertujuan untuk merumuskan strategi dalam mengintegrasi pendidikan dan kewirausahaan pada Institut Agama Islam Negeri (LAIN) Bukittinggi guna menghasilkan lulusan yang aplikatif dan berdaya saing tinggi. Setelah dianalisis dengan menggunakan analisa SWOT, Matrix SWOT, dan Tabel Bobot Skor, maka dapat dikemukakan bahwa strategi yang tepat adalah dengan menerapkan kurikulum KKNI yang sesuai dengan kebutuban pasar, mengembangkan kurikulum terutama mata kuliah kewirausahaan, membekali mahasiswa dengan pengetahuan kewirausahaan yang memadai, dan membuat program-program pelatihan kewirausahaan, seperti mengadakan unit-unit usaha mahasiswa untuk pengembangan potensi wirausaha mahasiswa, serta memperbanyak praktek-praktek kewirausahaan mahasiswa, melalui kerjasama dengan para pelaku usaha.

Kata kunci: integrasi, pendidikan, kewirausabaan 


\section{Introduction}

It is an imperative for the State Islamic Institute of Bukittinggi to be able to produce graduates who can compete with other university graduates to get jobs in government agencies, private companies, and even in creating jobs (entrepreneurship). Therefore, State Islamic Institute of Bukittinggi needs to prepare its graduates to have knowledge and skills as their competencies to face the world of work. Students or graduates will acquire mastery of knowledge through the education process, while at the same time they will acquire mastery of skills through training, both on and off campus.

State Islamic Institute of Bukittinggi is one of the higher education institutions that has a function as agent of change in society. When universities are ready to respond to the various changes that occur in their environment, they also always open to making various internal paradigm changes and that is the time when the function will run effectively.

From the research conducted on graduates of State Islamic Institute of Bukittinggi from year 2017 to 2019, it can be seen that around $20 \%$ of graduates work in the formal sector such as being civil servants and employees in private companies, while those working in the informal businesses sector such as self-employment is only $29 \%$, while the others, about $51 \%$, have not yet found a permanent job or are unemployed.

The low absorption of graduates of the State Islamic Institute of Bukittinggi in the formal sector is due to the fact that many graduates do not have the skills required by the business world or the formal sector. Meanwhile, the lack of graduates taking part in the entrepreneurial world is due to the lack of entrepreneurial knowledge and skills that can be applied or demonstrated in the real world or the world of work. Moreover, the lack of entrepreneurial graduates is due to the assumption of students or graduates that being an entrepreneur is a job that faces obstacles and risks and does not guarantee the future. These are all problems faced by graduates of the State Islamic Institute of Bukittinggi in responding to the world of work.

One of the fundamental problems found at the State Islamic Institute of Bukittinggi regarding entrepreneurship courses is the form of learning design, which so far has been submitted by the compilers to each study program, so that the final goal expected from entrepreneurship courses has not reached the target. This entrepreneurship course is considered as a course in the form of a theory that only presents an explanation of the general picture of entrepreneurship, without being accompanied by the formation of student entrepreneurial skills.

There is no uniformity in Semester Learning Plan (Rencana Pembelajaran Semester/RPS) which is oriented or directed to produce business entrepreneurs becoming owner entrepreneurs or independent entrepreneur candidates who are able to establish businesses, manage companies, and can enter the world of business and industry professionally. In addition, the implementation of learning has not been accompanied by a relatively complete and comprehensive educational operation in the form of workshops, training on entrepreneurship, and the absence of a business consulting agency.

From the above information, with the entrepreneurial knowledge and skills they have, many business fields can be created in accordance with the competence of each programme of study, such as the counselling programme can create employment in the field of counselling services; the English study programme has business opportunities in the courses or the study guidance services. The Islamic family law study programme has a business opportunity in the field of Islamic family law consulting services or becomes an 
Islamic preacher; the Sharia bank study programme has a business field in the field of Islamic microfinance institutions. In addition, the Islamic Economics Study Program is designed to provide young entrepreneurs with broader business opportunities, including in the fields of multi-services, workshops, printing, culinary and travel agencies, and others.

The State Islamic Institute of Bukittinggi, as one of the higher education institutions, is responsible for providing education in general and is also capable of providing entrepreneurship education to students through changes in entrepreneurship learning methods, materials, and lecturers. It is expected that it will be able to respond and overcome unemployment that increase over time, create jobs that are increasingly limited.

Several researchers have conducted some studies about entrepreneurship. First, Bharata states that the entrepreneurship is important for students as prospective workers. Therefore, it is necessary for the government to support entrepreneurship, through entrepreneurship education programs, especially in universities. ${ }^{1}$ Entrepreneurship has become a compulsory subject for every study program at the State Islamic Institute of Bukittinggi, which is an institutional course; however, it has not been implemented effectively and optimally.

Second, Isrososiawan concludes that entrepreneurial education or knowledge is intended to shape the entrepreneurial knowledge and skills of students or graduates that can be applied in the real world. As a result, it seems that entrepreneurial knowledge and skills are needed for higher education. It is as one of the efforts in forming the competent

1 Wira Bharata, Pengaruh Pendidikan Kewirausahaan Dan Motivasi Usaha Terhadap Minat Berwirausaha (Studi Pada Mahasiswa Fakultas Ekonomi Universitas Muhammadiyah Ponorogo)', Capital: Jurnal Ekonomi Dan Manajemen, 2.2 (2019), p, 98 <https://doi.org/10.25273/capital.v2i2.3985>. graduates in responding to the world of work, including the State Islamic Institute of Bukittinggi. $^{2}$

Third, Rintasari suggests that there is an influence of entrepreneurship education on student entrepreneurial interests. ${ }^{3}$ At the State Islamic Institute of Bukittinggi, the offering of entrepreneurship courses is expected to generate interest in students or graduates to carry out entrepreneurial activities. This is an alternative that may be done by graduates after graduating, in addition to continuing their education to a higher level or getting a job in the formal sector.

Fourth, Agung states that entrepreneurship education is one of the factors that can foster the entrepreneurial spirit of students. ${ }^{4}$ The presence of entrepreneurship education at the State Islamic Institute of Bukittinggi is also hoped be able to foster the entrepreneurial spirit of students or graduates, which can be realized in the real world or the world of work.

Next, from the results of the research, Glisna argues that student entrepreneurial interest can be influenced by entrepreneurship courses and educational institutions. ${ }^{5}$ At the State Islamic Institute of Bukittinggi, to encourage and generate student entrepreneurial interest, each study program must offer entrepreneurship courses, where entrepreneurship courses are used as mandatory institutional subjects.

2 Safroni Isrososiawan, 'Peran Kewirausahaan Dalam Pendidikan', Jurnal Jurusan Pendidikan IPS Ekonomi Jiwa, ix (2013), p, 26-49.

3 Nugraheni Rintasari and others, 'Kuliah Kewirausah aan , Berpengaruhkah Pada Minat Berwirausaha ?', 2 (2019), 111-28.

4 Anak Agung Gde Mantra Suarjana and Luh Mei Wahyuni, 'Faktor Penentu Minat Berwirausaha Mahasiswa (Suatu Evaluasi Pembelajaran)', Jurnal Bisnis Dan Kewirausabaan, 13.1 (2017), p, 11-22 <https://doi.org/10.31940/jbk.v13i1.687>.

5 Dwinooor Glisna, 'Pengaruh Pendidikan Kewirausahaan Terhadap Minat Berwirausaha Mahasiswa', Jurnal Ilmiah STIE MDP: Forum Bisnis Dan Kewirausabaan, 1.2 (2016), 112-19. 
Then, from the results of Wedayanti's research suggests that entrepreneurship courses are not only limited to theory but must also be followed by entrepreneurial practice in building student skills, through practice in entrepreneurship laboratories or direct practice in the field. ${ }^{6}$ At the State Islamic Institute of Bukittinggi, for the formation of student entrepreneurial skills, in addition to practice in the laboratory, direct practice can also be carried out in the field through the Student Entrepreneurship Program (Program Wirausaha Mahasiswa/PWM).

Seventh, based on the results of Adniyana's research, it is suggested that education and entrepreneurship can influence student interest in carrying out entrepreneurial activities. ${ }^{7}$ Therefore, to foster an interest or entrepreneurial spirit for students, it is necessary for higher education institutions to offer entrepreneurship courses for students as a compulsory subject. At the State Islamic Institute of Bukittinggi specifically for the Faculty of Economics and Islamic Business (Fakultas Ekonomi dan Bisnis Islam/FEBI), entrepreneurship courses are offered in several semesters.

Eighth, Kusmintarti's research result suggests that education and entrepreneurship have a positive effect on entrepreneurial attitudes of students. ${ }^{8}$ The presence of entrepreneurship education in universities will foster entrepreneurial attitudes for students. Attitude formation is something that must be

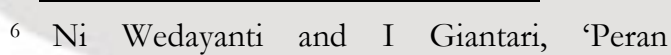
Pendidikan Kewirausahaan Dalam Memediasi Pengaruh Norma Subyektif Terhadap Niat Berwirausaha', E-Jurnal Manajemen Universitas Udayana, 5.1 (2016), 255039.

7 I. Adnyana and N. Purnami, 'Pengaruh Pendidikan Kewirausahaan, Self Efficacy Dan Locus of Control Pada Niat Berwirausaha', E-Jurnal Manajemen Universitas Udayana, 5.2 (2016), 253915.

8 Anik Kusmintarti, Nur Indah Riwajanti, and Andi Asdani, 'Pendidikan Kewirausahaan Dan Intensi Kewirausahaan Dengan Sikap Kewirausahaan Sebagai Mediasi', Journal of Research and Applications: Accounting and Management, $2.2 \quad$ (2017), $\quad$ p, 119 <https://doi.org/10.18382/jraam.v2i2.160>. done in entrepreneurship. Therefore, in entrepreneurship courses, in addition to the mastery of knowledge and skills, it is also necessary to form entrepreneurial attitudes towards students.

The above statement is also strengthened as the results of Sukirman's research, which suggests that the integration of knowledge and entrepreneurship will be able to change student behavior. ${ }^{9}$ Entrepreneurial knowledge or entrepreneurship education is one of the efforts that need to be given to students to change the entrepreneurial behavior or attitudes of students of State Islamic Institute of Bukittinggi, which can become their competency in responding to the world of work.

Last, the results of Faris' research, states that entrepreneurial knowledge and skills are provisions for students to be able to live independently, they are not as job seekers, but as job creators. ${ }^{10}$ Not all of the graduates of State Islamic Institute of Bukittinggi are civil servants, or as company employees. Therefore, referring to the results of Faris' research above, entrepreneurial knowledge and skills can be used as a provision for their life, by creating employment, which brings benefits to individuals, and also to others.

Based on the above background, several problems can be mentioned, namely, 1) the number of graduates of the State Islamic Institute of Bukitttinggi who do not have any competencies from year to year is increasing, and 2) the absorption of graduates of the State Islamic Institute of Bukittingi in the formal sector is low. Based on these problems, the

9 Universitas Muria kudus S Sukirman, 'Jiwa Kewirausahaan', Jiwa Kewirausahaan dan Nilai Kewirausahaan Meningkatkan Kemandirian Usaba Melalui Perilaku Kewirausahaan, 20.1 (2017), 113-32.

10 Faris Nur, 'Pengembangan Pendidikan Kewirausabaan Di Sekolah Dasar', Seminar Nasional Pendidikan PGSD UMS \& HDPGSDI Wilayah Jawa, 2017, 146-53. 
writers feel it is important to investigate further related to the strategy of integration of education and entrepreneurship at the State Islamic Institute of Bukittinggi in producing applicative competent graduates.

Curriculum can be seen from three points of view, namely the curriculum as a set of courses, as a learning experience, and as a learning program planning. So, it can be argued that when talking about curriculum, it depends on where we look at it or see it, whether in terms of a set of courses or learning experiences, and/or program planning, which contextually is what curriculum means. ${ }^{11}$

Sartika argues that the curriculum in tertiary institutions has undergone several changes in 1659, including in 1994, the enactment of the curriculum, which prioritized the achievement of mastery of science and technology, which was content based. In 2000, there was Competency Based Curriculum (KBK). Then in 2012, the curriculum of the Indonesian National Qualifications Framework (Kerangka Kualifikasi Nasional Indonesia/KKNI), in which each study program in tertiary institutions aims at the formation of human resources and labor which does not only refer to formal educational qualifications but also informal education (training, independent lessons, and work experience). ${ }^{12}$

Curriculum is something that is very important in the educational process, in addition to management and services to students. The curriculum in higher education is known as the Competency-Based Curriculum (KBK), which was later developed into the curriculum of Indonesian National Qualifications Framework (KKNI).

11 Wina Sanjaya, Pembelajaran Dalam Implementasi Kurikulum Berbasis Kompetensi, (Jakarta: Kencana Persada Media Group, 2011, h. 2)

12 Nasution Sartika, Dewi, 'Urgensi Fintech Dalam Kurikulum Pendidikan Tinggi', IqtIshaduNa Jurnal Ekonomi Syariah, 8.2 (2017), 116-29.
In the competency-based curriculum, competency is knowledge, skills, and abilities that can be learned and developed by students. The relation to this paper is how to create competent students or graduates who master the knowledge and skills so that they can apply them to the real world or the world of work.

In the KKNI, competencies or abilities are formulated in the form of learning outcomes. In the National Standard for Higher Education (SN Dikti), learning outcomes consist of attitudes, skills (general skills and special skills), and knowledge. The relation to this paper is how a strategy integrating education or knowledge with entrepreneurship or skills in creating competent graduates, so that they can realize or apply it in real life or the world of work.

Knowledge is the mastery of concepts, theories and methods that can be obtained through the educational process. In relation to this paper, what the author means by education is the mastery of certain disciplines or fields of knowledge that have something to do with the formation of entrepreneurial competencies for students or graduates, so that with this mastery they can apply it in real life or the world of work.

Skills are the ability to do work using concepts, theories and methods. In relation to this research, what is meant by entrepreneurship is the skills possessed by students or graduates, for certain jobs that are productive or produce in terms of material. So that with the skills in a field of work or business they have, this can be used as a profession for them. From this profession as entrepreneurs will bring income for them. It is expected that further than that, from the business they are doing, it can create jobs and provide income to other parties.

Entrepreneurship is a form of creative and innovative abilities possessed by a person, which allows someone to be able to create 
something in the form of goods or services. ${ }^{13}$ From the goods or services produced, it can provide benefits to themselves in the form of income, and to others as a fulfillment of their life needs for these goods or services.

Didip argues that entrepreneurship is a discipline that studies a person's abilities and behavior in facing the challenges of life. Entrepreneurship is a scientific discipline that prioritizes application or practice in addition to theory. Thus, the entrepreneurship courses offered to students are more into practies through practice in entrepreneurship laboratories, and student entrepreneurship programs. At the State Islamic Institute of Bukittinggi, student entrepreneurship activities are called the Student Entrepreneurship Program (Program Wirausaha Mahasiswa/PWM), which is a program that can realize student entrepreneurial knowledge in the real world. ${ }^{14}$

Virza argues that entrepreneurship is often defined as a person's ability to create something of value for others. ${ }^{15}$ Creating something, good or service, is a noble worker because from the activity of producing goods or services, it can meet the needs of many people. The more people of a nation, the more they need goods and services, which can be produced through the business world or entrepreneurship.

Kewirausahaan: Pedoman Praktis,

13 Suryana, Kewirausahaan: Pedoman Praktis, Kiat dan Proses Menuju Sukses, (Jakarta: Penerbit Salemba Empat, 2003, h.1)

14 Didip Diandra, 'Program Pengembangan Kewirausahaan Untuk Menciptakan Pelaku Usaha Sosial Yang Kompetitif, Jurnal.Polban.Ac.Id, 2016, p, 138-46

$<$ https://jurnal.polban.ac.id/proceeding/article/view/ $214>$.

15 Virza Utama, 'Analisa Pengaruh Entrepreneurial Education Terhadap Entrepreneurial Intention Dengan Menggunakan Fintech Adoption Sebagai Variabel Intervening Pada Mahasiswa Jurusan Bisnis-Manajemen', JPEK : Jurnal Pendidikan Ekonomi Dan Kewirausahaan, 4.1 (2020), p, 82-94 <https://doi.org/10.29408>.
According to Saragih, entrepreneurship is a creative and innovative ability. ${ }^{16}$ The ability to develop ideas in the form of creativity and innovation is a form of entrepreneurship possessed by an entrepreneur. With the existence of entrepreneurship education will form students who are observant of business opportunities that will be run after finishing college.

According to Wibowo, competency is the ability that a person has to carry out a certain job or task, it will be based on knowledge and skills he has. ${ }^{17}$ In the relation to this paper, the competencies possessed by graduates are based on knowledge or education, and skills or entrepreneurship that can be applied in real life or the world of work.

Sumarno and Gimin argue that entrepreneurship education consists of contents, methods, and activities which are aimed at providing knowledge, thought patterns, attitudes, motivation, skills, and entrepreneurial experience. ${ }^{18}$ Entrepreneurship education is given to students in order to provide knowledge and skills in entrepreneurship, so that after graduating from college, it can be a provision for their own life.

Rafika states that the goal of entrepreneurship education is to develop and arouse student intentions to become entrepreneurs. 19 From entrepreneurship

16 R. Saragih, 'Membangun Usaha Kreatif, Inovatif dan Bermanfaat Melalui Penerapan Kewirausahaan Sosial', Jurnal Kewirausahaan, 3.2 (2017), 26-34.

17 Wibowo, Manajemen Kinerja, Jakarta: RajaGrafindo, 2007, h.86)

18 Sumarno dan Gimin, 'Analisis Konseptual Teoretik Pendidikan Kewirausahaan Sebagai Solusi Dampak Era Industri 4.0 Di Indonesia', JURNAL PENDIDIKAN EKONOMI: Jurnal Ilmiah Ilmu Pendidikan, Ilmu Ekonomi Dan Ilmu Sosial, p, 13.2 (2019), $1<$ https://doi.org/10.19184/jpe.v13i2.12557>.

$\begin{array}{ccr}19 & \text { Rafika Rahmadani, 'Analisis } & \text { Faktor-Faktor } \\ \text { Yang } & \text { Mempengaruhi } & \text { Pendidikan } \\ \text { Kewirausahaan(Entrepreneurship } & \text { Education) Di }\end{array}$ 
education provided by universities to realize the entrepreneurial spirit of students and graduates, it can serve as competency for graduates in responding to the world of work.

Rizky Dwi Putri states that entrepreneurship education in tertiary institutions has been facilitated by the Higher Education since 1997 by integrating entrepreneurship education in the curriculum. ${ }^{20}$ Therefore, the State Islamic Institute of Bukittinggi includes Entrepreneurship as an institute compulsory subject.

According to Lestari and Wijaya in Eka's book, entrepreneurship education can shape the mindset, attitude, and behavior of students to become true entrepreneurs. ${ }^{21}$ This will be able to form competencies in entrepreneurship, which can be used as asset for life in the real world after graduating.

$\mathrm{Ni}$ Made states that the entrepreneurial knowledge given at universities is expected to be able to increase student interest in entrepreneurship. ${ }^{22}$ Interest or motivation in entrepreneurship is something important, so in entrepreneurship learning, it is necessary to make efforts to instill an interest in carrying out entrepreneurial activities.

Bharata suggests that entrepreneurship education is an important method in encouraging student entrepreneurship. It can be through formal and informal educational institutions. ${ }^{23}$ Entrepreneurship education is

Perguruan Tinggi Negeri Kota Bandung', SOSIODID AKTIKA: Social Science Education Journal, 1.1 (2018), 47-53 <https://doi.org/10.15408/sd.v1i1.9522>.

${ }^{20}$ Riza Megasari Rizky Dewi Putri, 'Pendidikan

Kewirausahaan Berbasis Pembelajaran Kolaboratif Untuk Internalisasi Karakter Wirausaha Di Pendidikan Tinggi', Jurnal Pendidikan Ekonomi, 11.2 (2018), 151-59.

21 Eka Yuli Lupitasari, 'Pendidikan Kewirausahaan Dan Efikasi Diri Terhadap Kesiapan Berwirausaha Mahasiswa', Eklektik: Jurnal Pendidikan Ekonomi Dan Kewirausahaan, 1.2 (2019), 127 $<$ https://doi.org/10.24014/ekl.v1i2.7102>.

${ }^{22} \mathrm{Ni}$ Made, 'Peran Pengetahuan Dan Motivasi Terhadap Peningkatan Minat Berwirausaha Mahasiswa Universitas Pendidikan Ganesha', 4.1 (2020), 13-24. ${ }^{23}$ Bharata. not only obtained in formal education institutions such as higher education institutions, but can also be obtained at informal educational institutions, such as training institutions, trainings/workshops, and so on. The two educational institutions will provide synergy in forming the entrepreneurial competencies of students or graduates. It can be seen that entrepreneurship education is so important, especially at State Islamic Institute of Bukittinggi as a formal education institution, which has made "Entrepreneurship" as an institutional course.

Education and entrepreneurship should ideally be implemented in the long term, in the form of a continuous learning process. This is very reasonable, because in order to produce graduates who have the quality and entrepreneurial spirit, universities do not only need a curriculum, but universities must also prepare all supporting instruments so that the implementation of education and entrepreneurship achieves maximum results.

Some important aspects that must be prepared by State Islamic Institute of Bukittinggi to become an entrepreneurial institute are designing a clear and directed entrepreneurship curriculum in accordance with KKNI references, establishing appropriate methods for achievement, having competent teaching staff in the field of entrepreneurship, creating entrepreneurial atmosphere, as well as how universities design a gradual and sustainable learning process.

Wiratno argues that graduate competency is something that must be developed in accordance with the characteristics and character of the university itself. ${ }^{24}$ State Islamic Institute of Bukittinggi, located in West Sumatra, where most of the people are traders or entrepreneurs, are very

$24 \quad$ Wiratno,'Pelaksanaan Pendidikan Kewirausahaan Di Pendidikan Tinggi', Jurnal Pendidikan Dan Kebudayaan, 18.4 (2012), 454 <https://doi.org/10.24832/jpnk.v18i4.101>. 
supportive in developing the entrepreneurial spirit of students or graduates.

Dedi Saefulloh states that the desire or interest in entrepreneurship is one of the important studies for students. ${ }^{25}$ Student interest in entrepreneurship is the belief to run a business when they finish college. We hope that after finishing or graduating from college, these graduates can realize entrepreneurship in the business world or can create jobs for themselves and others.

Entrepreneurial competency is defined as knowledge, attitudes, and skills that are connected to each other. ${ }^{26}$ State Islamic Institute of Bukittingi provides knowledge, attitudes and skills through entrepreneurship courses, which are accompanied by entrepreneurship practice, and student entrepreneurship programs (PWM). Besides entrepreneurship courses, there are several supporting courses, such as introductory courses on business, introductory management and so on. Entrepreneurial competency is needed by entrepreneurs to be trained and developed in order to be able to produce the best performance in managing their business. ${ }^{27}$

Kurniawan states that entrepreneurial competency is the managerial capacity of company leaders. ${ }^{28} \mathrm{~A}$ company leader must have the ability to manage human resources,

${ }^{25}$ Deddy Saefuloh, 'Rekognisi Terhadap Peluang Bisnis Online Melalui Media Sosial Dan Hubungannya Dengan Minat Berwirausaha: Studi Kasus Mahasiswa Politeknik Negeri Bandung', Jurnal Bisnis Dan Kewirausahaan, $\quad 16.1 \quad$ (2020), $\quad$ p,12-23 <https://doi.org/10.31940/jbk.v16i1.1827>.

26 Nurjannatul Hasanah, 'Hubungan Kompetensi Kewirausahaan Dan Kinerja Usaha ':, 13.2, 27-38.

${ }^{27} \mathrm{~N}$ Islam, 'Growth Empirics: A Panel Data Approach', The Quarterly Journal of Economics, 1995 <http://www.jstor.org/stable/2946651> [accessed 21 November 2015].

28 Asep Kurniawan and Yun Yun, 'Pengaruh Kompetensi Kewirausahaan Dan Kelanggengan Usaha Terhadap Keunggulan Bersaing', Jurnal Inspirasi Bisnis dan Manajemen, $2.1 \quad$ (2018), $\quad 65$ <https://doi.org/10.33603/jibm.v2i1.998>. and other resources. At State Islamic Institute of Bukittinggi, especially at Faculty of Economics and Islamic Business, there are many courses that can provide students with knowledge and managerial skills.

Then, Sugandi also states that entrepreneurial competency is a combination of attitudes, knowledge, and skills which are interconnected. ${ }^{29}$ This is in line with the writings of Harfandi and Sonita who have tried to see the synergy of attitudes, knowledge, and skills in developing the entrepreneurial spirit of FEBI students at State Islamic Institute of Bukittinggi.

\section{Methods}

The population in this study was not limited, because the number of university graduates increases every year. From this population, a sample of 127 people was taken, based on nonrandom sampling. The sample was determined by the researcher from the object of the study using accidental sampling.

Techniques used in data collection consisted of collecting primary data and secondary data. Primary data were collected through; 1) questionnaire, 2) observation, and 3) interview. Interviews were used to complete the incomplete information from the results of questionnaires and observations.

After the data was collected, with regard to the strategy of integration of education and entrepreneurship at the State Islamic Institute of Bukittinggi in creating applicative competent graduates, qualitative data analysis can be used as follows: ${ }^{30}$

First, SWOT analysis which is an identification activity of the strengths $(\mathrm{S})$ and weaknesses (W) at the State Islamic Institute

29 Fahmi Sugandi and Tintin Suhaeni, 'Peran Kompetensi Kewirausahaan dalam Meningkatkan Kinerja Usaha Pada Industri Kreatif Subsektor Kerajinan Di Kota Bandung', 1374-86.

30 Freddy Rangkuti, Teknik Membedah Kasus Bisnis Analisis SWOT, (Jakarta: PT Gramedia Pustaka, 2014, h.226). 
of Bukittinggi, as well as the identification of opportunities (O) and threats ( $\mathrm{T}$ ) from outside, all of which will influence the strategy preparation.

In the SWOT analysis, it is also necessary to evaluate the factors that exist at the State Islamic Institute of Bukittinggi in the form of strengths (S) and weaknesses (W) through the Internal Factor Evaluation (IFE) technique. Meanwhile, to evaluate the factors that are outside the State Islamic Institute of Bukittinggi in the form of opportunities (O) and threats $(\mathrm{T})$ using the External Factor Evaluation (EFE) technique.

Second, the SWOT matrix is used to determine the alternative strategies used to formulate an integrated education and entrepreneurship strategy at the State Islamic Institute of Bukittinggi in creating applicative competent graduates, consisting of $\mathrm{SO}$ Strategy, ST Strategy, WO Strategy, and WT Strategy. ${ }^{31}$

Then, Table of Score Weight (Tabel Bobot Score /TBS) is used to determine the strategy used from the four alternative strategies contained in the SWOT matrix above, namely SO Strategy, ST Strategy, WO Strategy, and W'T Strategy,

\section{Finding and Discussion}

After conducting a SWOT analysis of the research results, it can be stated that the internal factors of State Islamic Institute of Bukittinggi which are the strengths ( $\mathrm{S}$ ) consist of KKNI curriculum has been implemented, entrepreneurship is used as an institutional course; there is learning achievement related to knowledge and skills; there are courses that support entrepreneurship; there are training activities for students; there is a student entrepreneurship program (PWM); there are business units that are carried out

31 Suwarsono Muhammad, Manajemen Strategik Konsep dan Alat Analisis, (Yogyakarta: UPP STIM YKPN, 2017, h.186) independently by students; there is entrepreneurial potential for students; there is a student environment that supports entrepreneurship; there are facilities and infrastructure of campus that support student entrepreneurship; and there are student internship activities in the business world.

Internal factors of State Islamic Institute of Bukittinggi which are weaknesses (W) consist of lack of student motivation to learn; lazy habits of students that do not support entrepreneurship; lack of student discipline towards time; there is a student perception that being a civil servant is safer and more secure in their future; there is a student perception that entrepreneurship is an alternative employment; there is a student perception that entrepreneurship is less promising for the future; there is still limited knowledge of student entrepreneurship; the absence of student skills in entrepreneurship; the limited number of semester credit hours $(\mathrm{SCH})$ for entrepreneurship courses in several study programs; limited time for students to use entrepreneurship laboratories; and limited lecturers in developing entrepreneurial ideas.

To evaluate the internal factors of State Islamic Institute of Bukittinggi, can be seen through the Internal Factor Evaluation (IFE) as shown in the following table:

Table 1. Internal Factor Evaluation (IFE)

\begin{tabular}{lccc}
\hline \multicolumn{1}{c}{ Internal Factors } & Weight & Rating & $\begin{array}{c}\text { The } \\
\text { value } \\
\text { of }\end{array}$ \\
\cline { 2 - 4 } & & & \\
\hline Strength (Strength) & & & 0,20 \\
\hline $\begin{array}{l}\text { The KKNI curriculum } \\
\text { has been implemented }\end{array}$ & 0,05 & 4 & 0,28 \\
\hline $\begin{array}{l}\text { Entrepreneurship is } \\
\text { used as an institutional } \\
\text { course }\end{array}$ & 0,07 & 4 & 0,18 \\
\hline $\begin{array}{l}\text { There is learning } \\
\text { achievement with } \\
\text { respect to knowledge } \\
\text { and skills }\end{array}$ & 0,06 & 3 & \\
\hline $\begin{array}{l}\text { There are courses that } \\
\text { support }\end{array}$ & 0,06 & 4 & 0,24 \\
\hline
\end{tabular}




\begin{tabular}{|c|c|c|c|}
\hline \multirow[b]{2}{*}{ Internal Factors } & \multicolumn{3}{|c|}{ IFE } \\
\hline & Weight & Rating & $\begin{array}{l}\text { The } \\
\text { value } \\
\text { of }\end{array}$ \\
\hline entrepreneurship & & & \\
\hline $\begin{array}{l}\text { There are training } \\
\text { activities for students }\end{array}$ & 0,06 & 4 & 0,24 \\
\hline $\begin{array}{l}\text { There is a student } \\
\text { entrepreneurship } \\
\text { program (PWM) }\end{array}$ & 0,06 & 4 & 0,24 \\
\hline $\begin{array}{l}\text { There are business } \\
\text { units that are carried } \\
\text { out independently by } \\
\text { students }\end{array}$ & 0,05 & 4 & 0,20 \\
\hline $\begin{array}{l}\text { There is } \\
\text { entrepreneurial } \\
\text { potential for students }\end{array}$ & 0,05 & 3 & 0,15 \\
\hline $\begin{array}{l}\text { There is a student } \\
\text { environment that } \\
\text { supports } \\
\text { entrepreneurship }\end{array}$ & 0,04 & 3 & 0,12 \\
\hline $\begin{array}{l}\text { There are facilities and } \\
\text { infrastructure of } \\
\text { campus that support } \\
\text { student } \\
\text { entrepreneurship }\end{array}$ & 0,05 & 4 & 0,20 \\
\hline $\begin{array}{l}\text { There are student } \\
\text { internship activities in } \\
\text { the business world }\end{array}$ & 0,05 & 4 & 0,20 \\
\hline $\begin{array}{l}\text { Total strength } \\
\text { (Strength) }\end{array}$ & 0,60 & & 2,25 \\
\hline $\begin{array}{c}\text { Weakness } \\
\text { (Weakness) }\end{array}$ & & & \\
\hline $\begin{array}{l}\text { Lack of student } \\
\text { motivation }\end{array}$ & 0,04 & 4 & 0,16 \\
\hline $\begin{array}{l}\text { The lazy habits of } \\
\text { students that do not } \\
\text { support } \\
\text { entrepreneurship }\end{array}$ & 0,04 & 4 & 0,16 \\
\hline $\begin{array}{l}\text { Lack of student } \\
\text { discipline towards time }\end{array}$ & 0,04 & 4 & 0,16 \\
\hline $\begin{array}{l}\text { There is a student } \\
\text { perception that being a } \\
\text { civil servant is safer } \\
\text { and more secure in his } \\
\text { future }\end{array}$ & 0,04 & 3 & 0,12 \\
\hline $\begin{array}{l}\text { There is a student } \\
\text { perception that } \\
\text { entrepreneurship is an } \\
\text { alternative } \\
\text { employment }\end{array}$ & 0,03 & 3 & 0,09 \\
\hline $\begin{array}{l}\text { There is a student } \\
\text { perception that }\end{array}$ & 0,03 & 3 & 0,09 \\
\hline
\end{tabular}

\begin{tabular}{|c|c|c|c|}
\hline \multirow[b]{2}{*}{ Internal Factors } & \multicolumn{3}{|c|}{ IFE } \\
\hline & Weight & Rating & $\begin{array}{c}\text { The } \\
\text { value } \\
\text { of }\end{array}$ \\
\hline $\begin{array}{l}\text { entrepreneurship is less } \\
\text { promising for their } \\
\text { future }\end{array}$ & & & \\
\hline $\begin{array}{l}\text { Limited knowledge of } \\
\text { student } \\
\text { entrepreneurship }\end{array}$ & 0,04 & 3 & 0,12 \\
\hline $\begin{array}{l}\text { Not yet formed } \\
\text { student skills in } \\
\text { entrepreneurship }\end{array}$ & 0,04 & 4 & 0,16 \\
\hline $\begin{array}{l}\text { Limited number of } \\
\text { semester credit units } \\
\text { (credits) for } \\
\text { entrepreneurship } \\
\text { courses in some study } \\
\text { programs }\end{array}$ & 0,04 & 3 & 0,12 \\
\hline $\begin{array}{l}\text { Limited time for } \\
\text { students to use } \\
\text { entrepreneurship } \\
\text { laboratories }\end{array}$ & 0,03 & 3 & 0,09 \\
\hline $\begin{array}{l}\text { Limitations of lecturers } \\
\text { in developing } \\
\text { entrepreneurial ideas }\end{array}$ & 0,03 & 3 & 0,09 \\
\hline $\begin{array}{l}\text { Total Weakness } \\
\text { (Weakness) }\end{array}$ & 0,4 & & 1,36 \\
\hline $\begin{array}{l}\text { Total Internal } \\
\text { Factors }\end{array}$ & 1 & & 3,61 \\
\hline
\end{tabular}

Source: Research results and processed.

After evaluating the internal factors of State Islamic Institute of Bukittinggi through the Internal Factor Evaluation (IFE) technique, the score was 3.61. Because it was greater than 2.50 , it meant that the internal factors of State Islamic Institute of Bukittinggi can be optimized in producing applicative competent graduates.

Then as for the external factors from State Islamic Institute of Bukittinggi which are opportunities (O) consisting of there is educational autonomy in the management of higher education; there is government attention to the world of education; there is government support in the development of micro, small and medium enterprises; there is a national university curriculum development; there is a national education standard that 
ensures the achievement of educational goals; the implementation of the KKNI curriculum in higher education; there is a curriculum that is offered in accordance with market needs; the availability of a curriculum that can foster independence; the availability of a curriculum structure that is integrated in the achievement of graduate competencies; there is an education system that supports the development of knowledge, attitudes, and skills; increasing business fields for entrepreneurs from time to time; and there are places for student internships / practices in the business world.

External factors of State Islamic Institute of Bukittinggi which pose a threat (T) consist of limitations in the absorption of labor in the formal sectors; limited education levels of entrepreneurs; limited knowledge in business management; limited asset in business development; the assumption that entrepreneurship is a job full of risks; limitations in the use of technology; the level of life necessities that are increasingly high; uncertain national economic conditions; traditional business management; an increase in the number of workforce from year to year; and increasingly limited PNS acceptance.

To evaluate the internal factors of State Islamic Institute of Bukittinggi, can be through the Internal Factor Evaluation (IFE) as shown in the following table:

Table 2. External Factor Evaluation (EFE)

\begin{tabular}{lllc}
\hline & \multicolumn{3}{c}{ EFE } \\
\cline { 2 - 4 } External Factors & $\begin{array}{c}\text { Weig } \\
\text { ht }\end{array}$ & $\begin{array}{c}\text { Rat } \\
\text { ing }\end{array}$ & $\begin{array}{c}\text { The } \\
\text { value } \\
\text { of }\end{array}$ \\
\hline $\begin{array}{l}\text { Opportunity } \\
\text { (Opportunity) }\end{array}$ & & & \\
\hline $\begin{array}{l}\text { There is educational } \\
\text { autonomy in the } \\
\text { management of higher } \\
\text { education }\end{array}$ & 0,06 & 4 & 0,24 \\
\hline $\begin{array}{l}\text { There is government } \\
\text { attention toward the } \\
\text { world of education }\end{array}$ & 0,06 & 4 & 0,24 \\
\hline
\end{tabular}

\begin{tabular}{|c|c|c|c|}
\hline \multirow[b]{2}{*}{ External Factors } & \multicolumn{3}{|c|}{ EFE } \\
\hline & $\begin{array}{c}\text { Weig } \\
\text { ht }\end{array}$ & $\begin{array}{l}\text { Rat } \\
\text { ing }\end{array}$ & $\begin{array}{l}\text { The } \\
\text { value } \\
\text { of }\end{array}$ \\
\hline $\begin{array}{l}\text { There is government } \\
\text { support in the } \\
\text { development of micro, } \\
\text { small and medium } \\
\text { enterprises }\end{array}$ & 0,06 & 4 & 0,24 \\
\hline $\begin{array}{l}\text { There is a national higher } \\
\text { education curriculum } \\
\text { development }\end{array}$ & 0,06 & 4 & 0,24 \\
\hline $\begin{array}{l}\text { The existence of a } \\
\text { national education } \\
\text { standard that ensures the } \\
\text { achievement of } \\
\text { educational goals }\end{array}$ & 0,06 & 3 & 0,18 \\
\hline $\begin{array}{l}\text { The implementation of } \\
\text { the KKNI curriculum in } \\
\text { higher education }\end{array}$ & 0,06 & 4 & 0,24 \\
\hline $\begin{array}{l}\text { There is a curriculum } \\
\text { offered in accordance } \\
\text { with market needs }\end{array}$ & 0,05 & 4 & 0,20 \\
\hline $\begin{array}{l}\text { The availability of a } \\
\text { curriculum that can foster } \\
\text { independence }\end{array}$ & 0,05 & 4 & 0,20 \\
\hline $\begin{array}{l}\text { The availability of a } \\
\text { curriculum structure that } \\
\text { is integrated in the } \\
\text { achievement of graduate } \\
\text { competencies }\end{array}$ & 0,04 & 3 & 0,12 \\
\hline $\begin{array}{l}\text { There is an education } \\
\text { system that supports the } \\
\text { development of } \\
\text { knowledge and attitudes }\end{array}$ & 0,05 & 3 & 0,15 \\
\hline $\begin{array}{l}\text { There are places for } \\
\text { student internships / } \\
\text { practices in the business } \\
\text { world }\end{array}$ & 0,05 & 3 & 0,15 \\
\hline $\begin{array}{l}\text { Total Opportunity } \\
\text { (Opportunities) }\end{array}$ & 0,6 & & 2,20 \\
\hline Treath (threat) & & & \\
\hline $\begin{array}{l}\text { Limitations in the } \\
\text { absorption of labor in the } \\
\text { formal sectors }\end{array}$ & 0,04 & 4 & 0,16 \\
\hline $\begin{array}{l}\text { Limited educational level } \\
\text { of entrepreneurs }\end{array}$ & 0,04 & 3 & 0,12 \\
\hline $\begin{array}{l}\text { Limited knowledge in } \\
\text { business management }\end{array}$ & 0,04 & 4 & 0,16 \\
\hline $\begin{array}{l}\text { Limited asset in business } \\
\text { development }\end{array}$ & 0,04 & 3 & 0,12 \\
\hline $\begin{array}{l}\text { There is an assumption } \\
\text { that entrepreneurship is a }\end{array}$ & 0,03 & 3 & 0,09 \\
\hline
\end{tabular}




\begin{tabular}{lllc}
\hline \multicolumn{1}{c}{ External Factors } & $\begin{array}{c}\text { Weig } \\
\text { ht }\end{array}$ & $\begin{array}{c}\text { Rat } \\
\text { ing }\end{array}$ & $\begin{array}{c}\text { The } \\
\text { value } \\
\text { of }\end{array}$ \\
\cline { 2 - 4 } & & & \\
\hline job full of risks & 0,04 & 3 & 0,12 \\
\hline $\begin{array}{l}\text { Limitations in the use of } \\
\text { technology }\end{array}$ & & & \\
\hline $\begin{array}{l}\text { The level of necessity of } \\
\text { life is getting higher }\end{array}$ & 0,03 & 3 & 0,09 \\
\hline $\begin{array}{l}\text { Uncertain national } \\
\text { economic conditions }\end{array}$ & 0,04 & 4 & 0,16 \\
\hline $\begin{array}{l}\text { Traditional business } \\
\text { management }\end{array}$ & 0,04 & 3 & 0,12 \\
\hline $\begin{array}{l}\text { The increase in the } \\
\text { number of the workforce } \\
\text { from year to year }\end{array}$ & 0,03 & 3 & 0,09 \\
\hline $\begin{array}{l}\text { Increasingly limited PNS } \\
\text { acceptance. }\end{array}$ & 0,03 & 3 & 0,09 \\
\hline $\begin{array}{l}\text { Total } \boldsymbol{T r} \text { Treath (threats) } \\
\text { Total External Factors }\end{array}$ & $\mathbf{0 , 4}$ & & $\mathbf{1 , 0 0}$ \\
\hline
\end{tabular}

Source: Research results and processed.

After evaluating the internal factors of State Islamic Institute of Bukittinggi through the Internal Factor Evaluation (IFE) technique, the score was 3.61. Because it was greater than 2.50 , it meant that the internal factors of State Islamic Institute of Bukittinggi can be optimized in producing applicative graduate competencies.

Then after that a SWOT analysis is carried out, as well as the calculation through IFE and EFE, then a SWOT Matrix can be prepared as shown in the following table:

Table 3. SWOT Matrix

\begin{tabular}{cll}
\hline \multirow{2}{*}{ Internal } & \multicolumn{2}{c}{ External } \\
\cline { 2 - 3 } Strength & \multicolumn{1}{c}{$\boldsymbol{S} \boldsymbol{O}$ Strategy } & \multicolumn{1}{c}{ Th Strategy $(\boldsymbol{T})$} \\
(S) & Optimizing & Optimizing \\
& existing strengths & existing strengths \\
& in order to get & in order to \\
& opportunities & minimalize the \\
& from outside & threats from \\
& & outside \\
\hline Weakness & WO Strategy & $\boldsymbol{W} \boldsymbol{T}$ Strategy \\
(W) & Minimizing & Minimizing \\
& existing & existing \\
& weaknesses in & weaknesses in \\
& order to get & order to \\
& opportunities & minimalize the \\
\hline
\end{tabular}

\begin{tabular}{lll}
\hline \multirow{2}{*}{ Internal } & \multicolumn{2}{c}{ External } \\
\cline { 2 - 3 } & \multicolumn{1}{c}{ Opportunity $(\boldsymbol{O})$} & \multicolumn{1}{c}{ Threat $(\boldsymbol{T})$} \\
\hline \multirow{3}{*}{ from outside } & threats from \\
& & outside
\end{tabular}

Source: Research results and processed.

From the SWOT matrix above, four alternative strategies for State Islamic Institute of Bukittinggi in producing applicative competent graduates, namely: 1) SO strategy, 2) ST strategy, 3) WO strategy, and 4) WT Strategy.

In the SO Strategy, State Islamic Institute of Bukittinggi in producing applicative competent graduates, can be through: implementing the KKNI curriculum that is in accordance with market needs, developing a curriculum or entrepreneurship course, realizing student knowledge and entrepreneurship according to learning outcomes, forming entrepreneurial attitudes and skills of students, implementing student entrepreneurship programs (PWM) in realizing entrepreneurship, creating student business units in opening job opportunities, developing student entrepreneurial potential, increasing entrepreneurial practices for students, and collaborating with business actors.

In the ST Strategy, State Islamic Institute of Bukittinggi in producing applicative competent graduates, can be through: improving student entrepreneurship education, increasing student entrepreneurial skills, increasing knowledge of business management, shaping student entrepreneurial attitudes and behavior, providing business risk knowledge, forming business units as a group, providing entrepreneurial training, instilling awareness in students in utilizing, and training students in using technological tools.

In the WO Strategy, State Islamic Institute of Bukittinggi in producing applicative competent graduates, can be through: increasing student learning motivation, increasing student discipline, 
improving student perceptions of entrepreneurship, convincing students that entrepreneurship is a noble job, convincing students that it is not only being a civil servant that can be more secure, increase students' entrepreneurial knowledge according to the achievements in KKNI, learn to look for business opportunities, and accustom students to think creatively.

In the WT Strategy, State Islamic Institute of Bukittinggi in producing applicative competent graduates, can be through; provide motivation to learn entrepreneurship to students, change students' lazy habits, get used to discipline in learning, train students to be able to think creatively, instill in students that an entrepreneurial spirit needs to be formed, make students aware that entrepreneurship can create jobs, and motivate students to be able to develop entrepreneurial spirit.

To determine the strategy of the State Islamic Institute of Bukittinggi in producing graduates who are competent and applicable, the Weight Score Table (TBS) can be used as follows:

Table 4. Table of Score Weight (TBS)

\begin{tabular}{cll}
\hline \multirow{2}{*}{ Internal } & \multicolumn{2}{c}{ External } \\
\cline { 2 - 3 } & \multicolumn{1}{c}{ Opportunity } & \multicolumn{1}{c}{ Threat } \\
& \multicolumn{1}{c}{$(\boldsymbol{O})$} & \multicolumn{1}{c}{$(\boldsymbol{T})$} \\
\hline Strength & Total Score & Total Score \\
$(\mathbf{S})$ & SO Strategy & ST Strategy \\
& $2,25+2,20=4, \mathbf{4 5}$ & $1,36+2,20=\mathbf{3 , 5 6}$ \\
\hline Weakness & Total Score & Total Score \\
(W) & WO Strategy & WT Strategy \\
& $2,25+1,32=\mathbf{3 , 5 7}$ & $1,36+1,32=\mathbf{2 , 6 8}$
\end{tabular}

Source: Research results and processed.

From table 4 above, it can be seen the total score for each strategy, where the SO Strategy has a total score of 4.45 , the ST Strategy has a total score of 3.56 , the WO Strategy has a total score of 3.57 , and the WT strategy has a total score of 2.68. So it can be argued that the SO Strategy has the highest total score. Based on these calculations, a strategy can be drawn up that can be implemented by State Islamic Institute of Bukittinggi in producing applicative and highly competitive graduates as follows.

\section{The implementation of the KKNI curriculum}

Viewed from the education system, there are two kinds of education, namely academic education and professional education. Academic education prioritizes the mastery of several scientific fields for bachelor's degree, and professional education is mastering more than one scientific field for the Baccalaureate Degree (DIII program). At State Islamic Institute of Bukittinggi, there are three kinds of education level, starting from Baccalaureate degree (DIII program), Bachelor's degree (S1), and Master's degree (S2).

The curriculum preparations of all study programs at State Islamic Institute of Bukittinggi are tailored to market needs. It is in order to make the graduates have no difficulties to find works, they can even create jobs or become entrepreneurs. Starting in the 2017/2018 academic year at State Islamic Institute of Bukittinggi, the KKNI curriculum has been implemented.

In the KKNI curriculum, competencies or abilities are formulated in the form of learning outcomes. In the National Standard for Higher Education (SN Dikti) learning outcomes consist of attitudes, skills (general skills and special skills), and knowledge. The relation to this paper is how the strategy of integrating education or knowledge with entrepreneurship or skills in realizing graduates who have competencies that can be applied to the world of business or the world of work, or in other words graduates who have the ability to apply entrepreneurial knowledge and skills in the real world as a source of life income for them. 


\section{The development of curriculum or entrepreneurship courses \\ Entrepreneurship is a compulsory} subject at State Islamic Institute of Bukittinggi considering the importance of entrepreneurship for students or graduates. By giving this entrepreneurship course to students, it is expected that it will become a provision for them after graduating from college. It is because entrepreneurship courses can form students or graduates to have creative and innovative abilities which are used as the basis for finding opportunities in facing the outside world.

In entrepreneurship courses, students are given knowledge about entrepreneurship such as; 1) Applicative knowledge, such as how to do a particular business or business, 2) Knowledge of duties and responsibilities in doing business, and 3) Knowledge of business management and organization. Then there are skills that must be possessed such as; 1) Skills in risk mitigation, 2) Skills in creating added value, 3) Managerial skills, 4) Communication and integration skills, and 5) Specific business engineering skills. ${ }^{32}$

In carrying out entrepreneurial activities, things that must be known in advance, namely, what kind of business will be done, who will do it, where it will be done, when it will be started, why is this business done, and how to do it. Regarding how to do it, of course starting from how to prepare what is needed, how to process the production, how to market the production, and how to develop the business. These are all forms of competency that can be applied to the business world.

32 Suryana, Kewirausahaan, Pedoman Praktis, Kiat dan Proses Menuju Sukses, Jakarta: Salemba Empat, 2003,h.3)
The implementation of knowledge and entrepreneurship in accordance with learning outcomes

Knowledge and entrepreneurship in this study are the knowledge related to entrepreneurship that must be possessed by students in creating applicative competent graduates. From the results of the research conducted on college graduates who have succeeded in working in companies, government agencies, and being entrepreneurs, it can be argued that the knowledge that students must master in creating applicative competent graduates, such as; Mastering how to design or develop business ideas, Mastering how to innovate in business or business, Mastering how to manage a business or business, Mastering how to make scientific decisions, and Mastering the product marketing strategies.

The mastery of knowledge and entrepreneurship is the basis for doing something in entrepreneurship. With regard to knowledge in developing business ideas and innovations, it is the basis for doing or producing something unique, so that the resulting product is preferred by consumers. Knowledge in management or business management are such as making scientific decision, developing the product marketing strategies, motivating oneself and others, managing and controlling others, and doing business. Knowledge in business management needs to be mastered in creating applicative competent graduates and is used wherever they work or do business.

\section{The forming of student entrepreneurial attitudes and} skills

Knowledge and entrepreneurship in this study are knowledge related to entrepreneurship that must be possessed by students in creating applicative competent graduates. From the results of research conducted on college graduates who have worked in companies, government agencies, 
and being entrepreneurs, it can be argued that attitudes must be manifested by students in creating competent graduates that are applicative and competitive.

In addition to mastery of knowledge, attitudes or behavior, skills in entrepreneurship are requirements that must be possessed by students of State Islamic Institute of Bukittinggi, so that they can create applicative or ready-to-use and competent graduates in the world of business. Graduates who have entrepreneurial competency will be able to create jobs, which can have an impact on reducing the unemployment rate in our country, improving people's economic life, reducing the crime rate caused by economic factors.

The Implementation of Student Entrepreneurship Program

The Student Entrepreneurship Program (PWM) is a form of real and practical experience for students of the FEBI study program of State Islamic Institute of Bukittinggi. The purposes of holding a student entrepreneurship program (PWM), are namely; 1) to equip students with knowledge and skills in doing business, 2) to form the attitude of professional entrepreneur candidates, and 3) to guide students towards the formation of professionalism, who have Islamic knowledge, skills, attitudes, and values in doing business. ${ }^{33}$

Equipping students with skills can also be carried out in practical subjects such as entrepreneurial practice, computer practice, accounting practice, mini bank practice, and student entrepreneurship programs, as well as entrepreneurship training, leadership training, and management training. These are all efforts to form competencies that are ready to use, and can be used wherever they are active, especially in the business world.

33 FEBI IAIN Bukittinggi, Buku Pedoman Program Wirausaha Mahasiswa (PWM), (Bukittinggi: IAIN Bukittinggi Press, 2017), p.3-5.

\section{The establishment of student business units}

Through the student entrepreneurship program, students are divided into groups, each of which creates a business organizational structure. After forming their business organizational structure, they make a business feasibility study or a business plan that they will carry out, such as printing, workshop, culinary, and other services. These business fields have been given to them in the entrepreneurship practical course, they just need to realize them in real business. Besides the business units or business fields that they practice in entrepreneurial practice courses, there are many other business fields that they can do, as cited in Kasali, et al. There are many business fields that students can choose, namely; ${ }^{34}$ 1) food and beverage, 2) handicraft business, 3) agriculture and agribusiness, 4) livestock sector and fishpond products, 5) knitting, embroidery, and lace, 6) screen printing, 7) publishing, 8) children's toys, 9) intellectual works, 10) consulting services, and so on. These are all types of businesses or business fields that graduates can do as a manifestation and application of their competencies.

\section{The development of student entrepreneurial potential}

Students have a lot of potential that can be developed. It really depends on the student's personality, and also cannot be separated from the role of educators or lecturers. In general, the students of PTKIN in Indonesia come from middle to lower economic background. Especially, most of the parents of students of State Islamic Institute of Bukittinggi are farmers.

In financing the needs of college, there are students who are independent due to limited income of their parents, such as

${ }^{34}$ Kasali, dkk, Modul Kewirausahaan, (Jakarta: Yayasan Rumah Peubahan, 2010), p.122 
working as a shop assistant for part time, selling snacks on campus, selling credit, selling hijab, selling various juices, photo copying, selling fried food, selling fruit, and many other businesses they do. All of this is done in order to help their parents to pay for their studies and lives. Indirectly, this condition provides a positive value in shaping the entrepreneurial spirit of these students. The development of student entrepreneurial potential in the formation of entrepreneurial skills can be through providing practical courses such as entrepreneurial practice, student entrepreneurship programs, and entrepreneurship training. These are all efforts in shaping entrepreneurial skills as competent graduates that can be applied in their lives.

The development of student entrepreneurial practices

In realizing entrepreneurial skills, students prioritize the practices of providing knowledge because entrepreneurial knowledge, in addition to lectures in the classroom, is also obtained from observations and experiences in the business world. Entrepreneurship lectures in the classroom do not need to take a large portion, what needs to be reproduced is practical. If possible, the institution provides entrepreneurial practice courses that can be carried out in entrepreneurship laboratories, or off-campus such as student entrepreneurship programs. Indeed, in reality, entrepreneurship is closely related to practice, in addition to knowledge. Therefore, universities need to increase entrepreneurial practice courses in creating competent graduates that are applicaative and used in the business world.

\section{The establishment of collaboration with business actors}

Higher education institutions need to collaborate with business actors or the business world, in addition to government agencies. This is a demand that must be made in the accreditation of institutions (institutions) and study programs. The more collaboration carried out by institutions with government agencies and private institutions, it will increase the assessment in the accreditation of study programs or accreditation of institutions. One of the goals of collaboration between institutions and the business world is in order to create compatibility between academics or curriculum with the needs of the business world because on one side, higher education institutions provide more academic theories to students, on the other side the business world does not necessarily apply theory - the theory students learn on campus. These considerations are made by universities in preparing a curriculum that adapts to market needs.

One form of cooperation between educational institutions and the business world is through the involvement of the business world in the formulation of the vision, mission and objectives of the institution and study program. The participation of the business world in providing an overview to educational institutions about the mastery and competencies that graduates must have so that they can be accepted in the business world or the world of work. Of course, the connection with entrepreneurship can also provide a source of knowledge and skills for students through apprenticeship activities at government agencies or companies that are engaged in both the monetary and real sectors. The more educational institutions that collaborate with the business world, the more opportunities it will provide for students to gain knowledge of business skills. In fact, there are times when they graduate or graduate from college, they are recruited to work in their place of apprenticeship. Of course, this is for those who are considered good by the company. 


\section{Conclusion}

In the SO Strategy, State Islamic Institute of Bukittinggi in producing applicative competent graduates can be through: implementing the KKNI curriculum that is in accordance with market needs, developing a curriculum or entrepreneurship course, realizing student knowledge and entrepreneurship according to learning outcomes, forming entrepreneurial attitudes and skills of students, implementing student entrepreneurship programs (PWM) in realizing entrepreneurship, creating student business units in opening job opportunities, developing student entrepreneurial potential, increasing entrepreneurial practices for students, and collaborating with business actors.

Based on the conclusion, suggestions can be made, namely: 1) for students of the State Islamic Institute of Bukittinggi, to be able to change lazy habits to be more active in studying for the better, foster self-confidence in doing entrepreneurship, get used to living independently, without depending on other parties, get used to discipline in using time, do not waste a lot of time, realizing that entrepreneurship is a noble job and must be done in life, and increasing skills in entrepreneurship in the form of increasing soft skills through training, entrepreneurship seminars, and 2) for State Islamic Institute of Bukittinggi, to compile a curriculum that supports student entrepreneurship education, provide teaching staff from practitioners who have an entrepreneurial spirit, and entrepreneurial knowledge, provide facilities that support entrepreneurship education in entrepreneurial laboratories as well as supporting facilities and infrastructure such as a place to expose business results, a showroom, increase the number of supporting entrepreneurship courses, and evaluate the implementation of the Student Entrepreneurship Program (PWM) through
Monev to business actors, students and lecturers.

\section{References}

\section{Book}

Kasali, Rhenal, Purnomo, Boyke, Nasution, Arman Hakim, Rustiadi, Sonny, Larso, Dewi, Mirzanti, Isti Raafaldini, Ciptarahayu, Agustina, Muliyana, Asep, dan Daryanto, Daryanto, dan Heny K, Modul Kewirausabaan. Jakarta: Yayasan Rumah Perubahan, 2010).

Muhammad, Suwarsono, Manajemen Strategike Konsep dan Alat Analisis, (Yogyakarta: UPP STIM YKPN, 2017)

Rangkuti, Freddy, Teknik Membedab Kasus Bisnis Analisis SWOT, (Jakarta: PT Gramedia Pustaka, 2014)

Suryana, Kewirausahaan, Pedoman Praktis, Kiat dan Proses Menuju Sukses, Jakarta: Salemba Empat, 2003,h.3

Uddin, Hazan, Teori Dasar Integrasi, Makalah, Jan 2013

Wibowo, Manajemen Kinerja, (Jakarta: RajaGrafindo, 2007)

Wina Sanjaya, Pembelajaran Dalam Implementasi Kurikulum Berbasis Kompetensi, (Jakarta: Kencana Persada Media Group, 2011)

Wibowo, Manajemen Kinerja, (Jakarta: RajaGrafindo, 2007)

Wina Sanjaya, Pembelajaran Dalam Implementasi Kurikulum Berbasis Kompetensi, (Jakarta: Kencana Persada Media Group, 2011)

\section{Journal}

Adnyana, I, and N. Purnami, 'Pengaruh Pendidikan Kewirausahaan, Self Efficacy Dan Locus of Control Pada Niat Berwirausaha', E-Jurnal Manajemen Universitas Udayana, 5.2 (2016), 253915.

Bharata, Wira, Pengaruh Pendidikan Kewirausahaan Dan Motivasi Usaha Terhadap Minat Berwirausaha (Studi Pada Mahasiswa Fakultas Ekonomi Universitas Muhammadiyah Ponorogo)', Capital: Jurnal Ekonomi Dan Manajemen, $2.2 \quad$ (2019), 98 $<$ https://doi.org/10.25273/capital.v2i2. $3985>$. 
Diandra, Didip 'Program Pengembangan Kewirausahaan Untuk Menciptakan Pelaku Usaha Sosial Yang Kompetitif, Jurnal.Polban.Ac.Id, 2016, 138-46 $<$ https://jurnal.polban.ac.id/proceeding /article/view/214>.

FEBI Institut Agama Islam Negeri (IAIN) Bukittinggi, Buku Pedoman Program Wirausaba Mahasiswa (PWM), (Institut Agama Islam Negeri (IAIN) Bukittinggi, 2017)

Faris Nur, 'Pengembangan Pendidikan Kewirausahaan Di Sekolah Dasar', Seminar Nasional Pendidikan PGSD UMS \& HDPGSDI Wilayah Jawa, 2017, 14653.

Glisna, Dwinoor, 'Pengaruh Pendidikan Kewirausahaan Terhadap Minat Berwirausaha Mahasiswa', Jurnal Ilmiah STIE MDP: Forum Bisnis Dan Kewirausahaan, 1.2 (2016), 112-19.

Hasanah, Nurjannatul 'Hubungan Kompetensi Kewirausahaan Dan Kinerja Usaha':, 13.2, 27-38.

Isrososiawan, dan Safroni, 'Peran Kewirausahaan Dalam Pendidikan', Jurnal Jurusan Pendidikan IPS Ekonomi Jiwa, ix (2013), 26-49.

Kusmintarti, Anik, Nur Indah Riwajanti, and Andi Asdani, 'Pendidikan Kewirausahaan Dan Intensi Kewirausahaan Dengan Sikap Kewirausahaan Sebagai Mediasi', Journal of Research and Applications: Accounting and Management, $2.2 \quad$ (2017), 119 $<$ https://doi.org/10.18382/jraam.v2i2.1 $60>$.

Made, Ni, 'Peran Pengetahuan Dan Motivasi Terhadap Peningkatan Minat Berwirausaha Mahasiswa Universitas Pendidikan Ganesha', 4.1 (2020), 13-24.

Megasari, Riza, Rizky Dewi Putri, 'Pendidikan Kewirausahaan Berbasis Pembelajaran Kolaboratif Untuk Internalisasi Karakter Wirausaha Di Pendidikan Tinggi', Jurnal Pendidikan Ekonomi, 11.2 (2018), 151-59.

Kurniawan, Asep, and Yun Yun, 'Pengaruh Kompetensi Kewirausahaan Dan Kelanggengan Usaha Terhadap Keunggulan Bersaing', Jurnal Inspirasi Bisnis Dan Manajemen, 2.1 (2018), 65
$<$ https://doi.org/10.33603/jibm.v2i1.9 $98>$.

Rahmadani, Rafika, 'Analisis Faktor-Faktor Yang Mempengaruhi Pendidikan Kewirausahaan(Entrepreneurship Education) Di Perguruan Tinggi Negeri Kota Bandung', SOSIO-DIDAKTIKA: Social Science Education Journal, 1.1 (2018), 47-53

$<$ https://doi.org/10.15408/sd.v1i1.952 $2>$.

Saragih, R 'Membangun USAha Kreatif, Inovatif Dan Bermanfaat Melalui Penerapan Kewirausahaan Sosial', Jurnal Kewirausabaan, 3.2 (2017), 26-34.

Saefuloh, Dedy, 'Rekognisi Terhadap Peluang Bisnis Online Melalui Media Sosial Dan Hubungannya Dengan Minat Berwirausaha: Studi Kasus Mahasiswa Politeknik Negeri Bandung', Jurnal Bisnis Dan Kewirausabaan, 16.1 (2020), 12-23 $<$ https://doi.org/10.31940/jbk.v16i1.18 $27>$.

Sartika, Nasition, Dewi, 'Urgensi Fintech Dalam Kurikulum Pendidikan Tinggi', IqtIshaduNa - Jurnal Ekonomi Syariah, 8.2 (2017), 116-29.

Sugandi, Fahmi, and Tintin Suhaeni, 'Peran Kompetensi Kewirausahaan Dalam Meningkatkan Kinerja Usaha Pada Industri Kreatif Subsektor Kerajinan Di Kota Bandung', 1374-86.

Sumarno dan Gimin, 'Analisis Konseptual Teoretik Pendidikan Kewirausahaan Sebagai Solusi Dampak Era Industri 4.0 Di Indonesia, JURNAL PENDIDIKAN EKONOMI: Jurnal Imiah Ilmu Pendidikan, Ilmu Ekonomi Dan Ilmu Sosial, 13.2 (2019), 1 <https://doi.org/10.19184/jpe.v13i2.12 $557>$.

Rintasari, Nugraheni, and others, 'Kuliah Kewirausah aan , Berpengaruhkah Pada Minat Berwirausaha?', 2 (2019), 111-28.

S. Sukirman, Universitas Muria kudus 'Jiwa Kewirausahaan', Jiwa Kewirausabaan Dan Nilai Kewirausahaan Meningkatkan Kemandirian Usaha Melalui Perilaku Kewirausahaan, 20.1 (2017), 113-32. 
Surjana, Anak Agung Gde Mantra Suarjana and Luh Mei Wahyuni, 'Faktor Penentu Minat Berwirausaha Mahasiswa (Suatu Evaluasi Pembelajaran)', Jurnal Bisnis Dan Kewirausabaan, 13.1 (2017), 11-22 $<$ https://doi.org/10.31940/jbk.v13i1.68 $7>$.

Utama, Virza, 'Analisa Pengaruh Entrepreneurial Education Terhadap Entrepreneurial Intention Dengan Menggunakan Fintech Adoption Sebagai Variabel Intervening Pada Mahasiswa Jurusan Bisnis-Manajemen', JPEK Jurnal Pendidikan Ekonomi Dan Kewirausahaan), $4.1 \quad$ (2020), 82-94 $<$ https://doi.org/10.29408>.

Wedayanti, Ni, and I Giantari, 'Peran Pendidikan Kewirausahaan Dalam Memediasi Pengaruh Norma Subyektif
Terhadap Niat Berwirausaha', E-Jurnal Manajemen Universitas Udayana, 5.1 (2016), 255039.

Wiratno,'Pelaksanaan Pendidikan Kewirausahaan Di Pendidikan Tinggi', Jurnal Pendidikan Dan Kebudayaan, 18.4 (2012), 454 $<$ https://doi.org/10.24832/jpnk.v18i4. $101>$.

Yuli, Eka, Lupitasari, 'Pendidikan Kewirausahaan Dan Efikasi Diri Terhadap Kesiapan Berwirausaha Mahasiswa', Eklektik: Jurnal Pendidikan Ekonomi Dan Kewirausahaan, 1.2 (2019), 127

$<$ https://doi.org/10.24014/ekl.v1i2.710 $2>$. 